総説

特集：自己抗体の産生機序とその病原性

膠原病における抗核抗体の産生機序とその病原性

藤井隆夫

\title{
The mechanisms of antinuclear antibody production and its pathogenicity in systemic autoimmune diseases
}

Takao FUJII

\begin{abstract}
Department of Rheumatology, and Clinical Immunology Graduate School of Medicine, Kyoto University
\end{abstract}
(Received February 13, 2006)

summary

Genesis of antinuclear antibodies is one of the most important immunological abnormalities that are closely associated with clinical manifestations, disease activity, and prognosis of systemic autoimmune diseases. Previous reports indicated that autoreactive $\mathrm{T}$ cells have critical roles not only in antinuclear antibody production but also in organ damages. Recently, the possible molecules that are involved in the mechanism of antinuclear antibody production have been determined by using lupus-prone mice. Target treatment against the key molecules associated with autoreactive $T$ cells and B cells may be the useful therapeutic strategy for systemic autoimmune diseases along with the suppression of disease-specific antinuclear antibody production.

Key words_ antinuclear antibodies; systemic lupus erythematosus; autoreactive T cells; MRL/lpr mice

抄 録

抗核抗体の検出は，膠原病の診断，活動性あるいは予後評価をする上できわめて重要である．その産生には B 細胞のみならず自己反応性 $\mathrm{T}$ 細胞が重要で，それらの cognate interaction に関与する共刺激分子の調節により抗核 抗体産生を制御できることが動物モデルで示されている. また特定の遺伝子をノックアウトすることで一部の抗核 抗体の産生抑制が可能で，生体内における抗核抗体の病因的意義も示されてきた. しかしながらヒト全身性エリテ マトーデスにおける数多くの抗核抗体の病因的意義はいまだ明確とはいえない．既存の治療法をこえる強力な病態 制御には, 疾患標識抗核抗体の産生に関与する分子を特異的なターゲットとし, 抗核抗体のみならず自己反応性 T 細胞や B 細胞などを含めた包括的な制御がより効果的であると考えられる.

\section{はじめに}

自己抗体は，自己免疫疾患においてもつとも重要 な免疫異常のひとつである. 自己免疫性溶血性貧血 や甲状腺自己免疫疾患, 重症筋無力症などの臓器特 異的自己免疫疾患では, それらの細胞や病態に関与 する機能分子に対する自己抗体が検出され，その診 断に関してきわめて有用な情報をもたらしているの と同時に，抗 TSH レセプター抗体のように病因的 意義が明確になっているものもある。これらは臓器 特異的な自己抗体で特徵づけられる臓器特異的自己 免疫疾患（organ-specific autoimmune disease）で

京都大学大学院医学研究科内科学講座臨床免疫学 ある。一方，膠原病など全身性自己免疫疾患（systemic autoimmune disease）では血清中に抗核抗体 が高頻度に検出されるが，その抗核抗体発見の端緒 となったのは Hargraves による LE 細胞の発見1)で ある。その後つぎつぎと新しい抗核抗体が報告さ れ2), 分子生物学の発展とも相まってその対応抗原 が明らかとされた3)。抗核抗体が認識する対応抗原 の CDNA が次々とクローニングされ，抗原蛋白の 精製が容易になったため, 現在では検査室で迅速に 測定できる抗核抗体も少なくない。一方で高頻度に 認められる抗核抗体についてはその臨床的意義も数 多く検証され，抗核抗体の測定は膠原病におけるも つとも特異的な検査として世界的に定着した。この ような抗核抗体に関する臨床研究の著しい進歩が, 
リウマチ・膠原病学の進歩に大きく貢献しているこ とは疑う余地がない。

近年では，その産生機序について患者検体のみな らずループスモデルマウスを用いた詳細な検討で多 くの知見が得られている. 特に自己反応性 $\mathrm{T}$ 細胞 の重要性や， T-B cognate interaction に関与する共 刺激分子を抑制することで抗核抗体の産生が制御で きることが示されている. 今後同様の治療が患者に 対して応用されていくと考えられるが，全身性エリ テマトーデス（SLE）患者における病原性が明確と なっている抗核抗体は少なく, いかなる抗核抗体を 標的とするかが問題となる，本稿では，膠原病にお けるより特異的で強力な免疫抑制療法の開発に向け て, 臨床の現場で特に遭遇することが多い抗 DNA 抗体と抗 U1RNP 抗体の病原性に関し, 治療標的と しての意義を考えてみる.

\section{抗核抗体産生に関する免疫学的特徵}

臨床的意義を有する抗核抗体の多くは表 1 にしめ す免疫学的特徵を有する。これらの免疫学的特徵 は, 抗核抗体の産生において B 細胞のみならず $\mathrm{T}$ 細胞が密接に関与している可能性を示唆してい る4,5). ループスモデルマウスである MRL/MpFas ${ }^{l p r / l p r}(\mathrm{MRL} / l p r)$ マウスにおいて T 細胞を遺伝 的に欠損した場合には抗核抗体の産生が認められ ず，ループス腎炎などの臨床症状が認められなくな る6).これは MRL/lpr マウスにおいて抗核抗体の 産生と病態の形成のために $\mathrm{T}$ 細胞が必須であるこ とを示すが，必ずしも $\alpha \beta T$ 細胞が必須というわけ ではない。それは $\mathrm{TCR}-\alpha^{-1-}$ 欠損 $\mathrm{MRL} / \mathrm{lp} r$ マウス においても, 抗 DNA 抗体の産生が認められ免疫複 合体性腎炎（ループス腎炎）の発症が認められるこ とにより証明されている7)。すなわち， $\gamma \delta \mathrm{T}$ 細胞も $\alpha \beta \mathrm{T}$ 細胞と同様, 少なからず $\mathrm{B}$ 細胞からの抗核抗 体の産生を刺激する機能を有していることを示唆す る.なお， $\gamma \delta \mathrm{T}$ 細胞のみを欠損した $\mathrm{MRL} / l p r$ マウ

\section{表 1 膠原病の病態と関連する抗核抗体の特徵}

Oligoclonality

MHC class II-restricted

Isotype switching

Affinity maturation

High titer

Epitope spreading

Recognition of functional particles
ス（TCR $\beta+/+$ TCR $\delta-/-\mathrm{MRL} / l p r$ マウス） で は野生型に比してもより強い病態を発現すること6) から， $\gamma \delta \mathrm{T}$ 細胞はむしろ抑制性 $\mathrm{T}$ 細胞としての機 能が優位であると考えられている。一方, pigeon cytochrome $c$ (PCC) に特異的に反応する $\mathrm{TCR}-\mathrm{T}$ 細胞のみを有する MRL/lpr マウス（AND TCR transgenic TCR $\alpha-/-$ TCR $\beta-/-\mathrm{MRL} / \operatorname{lp} r$ マウ ス）では，抗 DNA 抗体の産生は明らかに認められ るもののループス腎炎などの蔵器病変は認められな (18).この場合 $\mathrm{T}$ 細胞から分泌されたサイトカイン を介した bystander help による抗 DNA 抗体産生 B 細胞の非特異的な活性化と考えられている。 また $\mathrm{MRL} / l p r$ マウスや NZB/NZW F1 マウスでは抗 CD40 リガンド（CD40L, CD154）抗体によって抗 DNA 抗体の産生が抑制され, ループス腎炎が軽症 化すること9,10) から, T 細胞と B 細胞の cognate interaction（同一の抗原分子上の抗原決定基を認識す る 2 種類の細胞間直接接触を必要とする相互作用） が病態形成に必要で，ループス様症状の発現（ある いは病因的抗核抗体の産生刺激）には自己反応性 $\mathrm{T}$ 細胞が重要な役割を果たしていることが強く示唆さ れる（図 1)。

\section{自己反応性 $\mathbf{T}$ 細胞とトレランス}

Mamula らは抗 RNP Ig トランスジェニック（2$12 \mathrm{Tg}$ ）マウスを作成し，ループスモデルマウスに おける自己反応性 $\mathrm{T}$ 細胞の存在を明らかにし た ${ }^{11)}$. 彼らは正常 B10.A, B6 マウスおよび MRL/ $l p r$ マウスをバックグラウンドとし, 抗 RNP Ig 卜 ランスジェニックマウスを作成したが, 抗 RNP Ig トランスジェニック B10.A および B6 マウス血清中 には抗 U1RNP 抗体は検出されずループス腎炎は発 症しなかった。 また同マウスから分離した $\mathrm{T}$ 細胞 は, RNP Ig トランスジェニック B 細胞と反応しな かった。一方, MRL/lpr マウスをバックグラウン ドとした場合には，血清中に抗 U1RNP 抗体が検出 され，糸球体腎炎に加えて間質性病変の増悪を認め た。 また彼らは抗 RNP Ig トランスジェニック B 細胞が認識する RNP D 蛋白に反応する $\mathrm{T}$ 細胞の存 在も確認した。これらの結果から，正常マウスにお ける自己反応性 $\mathrm{B}$ 細胞は, 必ずしも自己反応性 $\mathrm{T}$ 細胞（正常マウスにも存在する）を活性化すること はなく，むしろそのトレランスを誘導することが示 された。一方で MRL/lpr (autoimmune) バックグ ラウンドでは自己反応性 B 細胞は積極的に自己反 


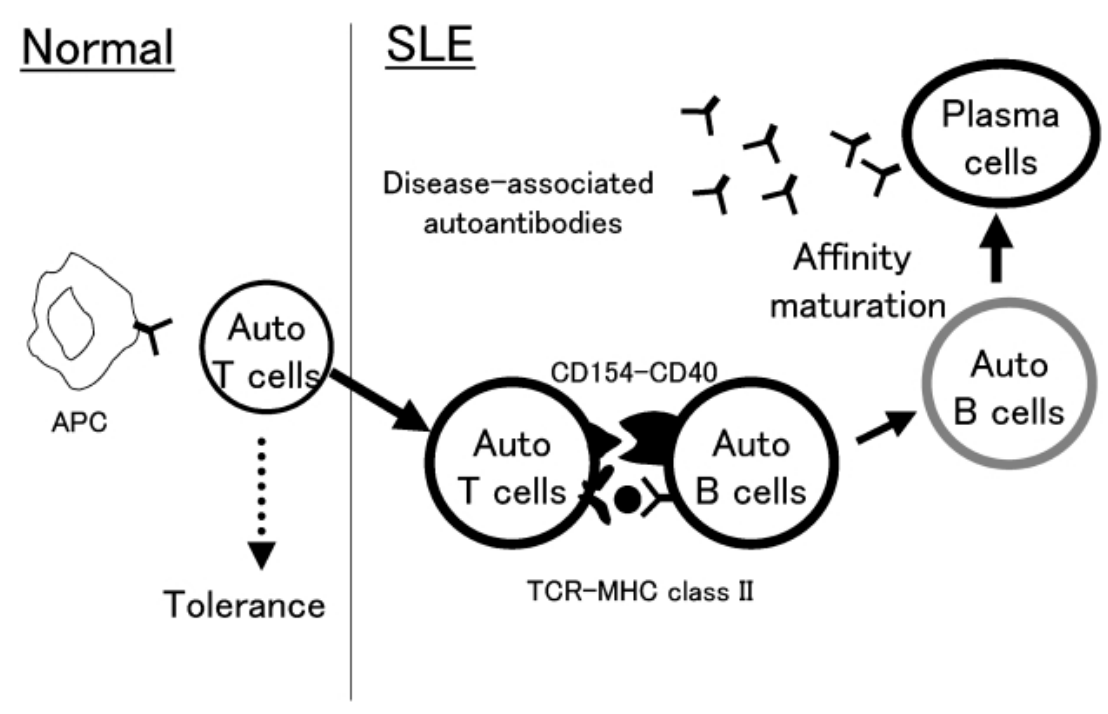

図 1 SLE の病態に関連する抗核抗体の産生機構

健常人あるいは正常マウスでは自己反応性 T 細胞はトレランス（免疫寛容）の状態となるのに対し，SLEや MRL/lpr マウスな ぞ自己免疫疾患では自己反応性 $\mathrm{T}$ 細胞のトレランスが破綻し，B 細胞と cognate interactionにより B 細胞は成熟分化し，形質細 胞となって抗核抗体を産生する。 また自己抗原の繰り返し刺激により，抗原親和性は高くなる．その結果，抗 DNA 抗体など疾 患あるいは病態と関連する抗核抗体が産生される. 抗原提示細胞としての B 細胞や樹状細胞の異常も関連すると考えられる. CD40 リガンド（CD40L，CD154）は B 細胞から分泌される免疫グロブリンのクラススイッチに必須の分子であり，特に SLE 患 者では活性化している。

APC, antigen-presenting cells

応性 $\mathrm{T}$ 細胞を活性化する。 すなわち, 自己反応性 $\mathrm{B}$ 細胞はそのバックグランドにより自己反応性 $\mathrm{T}$ 細胞に及ぼす影響が異なるか，正常（non-autoimmune）では自己反応性 $\mathrm{T}$ 細胞を抑制する機序が存 在する可能性が考えられる，後者に関しては，近年 注目されている抑制性 $\mathrm{T}$ 細胞 $\left(\mathrm{CD} 4{ }^{+} \mathrm{CD} 25^{+} \mathrm{T}\right.$ 細 胞）数が, SLE 患者において減少しているとする 報告がある12)。一方でそれら制御機構を有していて も自己反応性 $\mathrm{T}$ 細胞の異常によってそのトレラン スが破綻してしまうことが知られている，その機序 とし，自己反応性 B 細胞の関与13)，ループス CD4 陽性細胞による low affinity のペプチドに対する反 応性克進 ${ }^{14)}$, また $\mathrm{MRL} / \mathrm{lpr}$ マウスの $\mathrm{CD} 4{ }^{+} \mathrm{CD} 25^{-}$ $\mathrm{T}$ 細胞は抑制性 $\mathrm{T}$ 細胞に対する反応性が弱いとす る報告 ${ }^{15)}$ などがある。このような自己反応性 $\mathrm{T}$ 細 胞の過㮃増殖を制御する機構の再活性化（たとえば 抑制性 $\mathrm{T}$ 細胞の活性化）により，病態に関連する $\mathrm{T}$ 細胞のトレランスを再度誘導することができれ ば，それは効果的な治療法の一つとなるであろう。

\section{B 細胞トレランス破綻の機序}

一方で B 細胞トレランスの破綻に関しても多く の知見がある. 免疫グロブリンのクラススイッチに 関して必須の分子である CD40L (CD154) を B 細 胞表面上に異所性に発現させた正常マウス（B6 マ
ウス）では, 抗 DNA 抗体の産生が認められ免疫複 合体性腎炎が発症する16)。SLE 患者末梢血におい ては， $\mathrm{T}$ 細胞の夕ならず $\mathrm{B}$ 細胞表面上でも $\mathrm{CD} 40 \mathrm{~L}$ の発現が充進していることが知られている17,18)こと から， T-B cognate interaction に関与する共刺激分 子の活性化はループス発症の引き金となる。 また B 細胞にはエストロゲンレセプターが発現している が，エストロゲンと反応することによって CD22や SHP-1の発現が充進し, B 細胞のアポトーシスが 抑制され，自己免疫疾患が発症する19).この成績は,

SLE 患者のほとんどが女性であることを支持する 成績であり, B 細胞の異常増殖が自己免疫を誘導す る可能性を示唆している.

近年ヒトSLE ではリツキシマブ（抗 CD20 モ） クローナル抗体）を用いた B 細胞の特異的な除去 によって症状が改善することが示されている20). 興 味深いのは, リツキシマブが B 細胞の除去ととも に, SLE における活性化 T 細胞表面の CD40L 発現 を制御している可能性がある点であろう。また CD20 は形質細胞には発現していないことから, リ ツキシマブは免疫グロブリン産生細胞を直接的に傷 害するわけではない。むしろリツキシマブ使用によ り患者血清中の $\mathrm{IgD}^{+} \mathrm{CD} 27^{-} \mathrm{B}$ 細胞が再構築さ れ21)，ヒトSLEにおいてトレランスが破綻してい るとされる mature naïve B 細胞以降22)が “リセッ 
ト”される結果，病態抑制に至った可能性が高い. このモノクローナル抗体による治療は, 抗核抗体や 自己抗体の抑制というより，その産生に関与する細 胞を包括的に抑制した治療といえるであろう. 今後 さらに臨床治験が進むと考えられるが, リツキシマ ブにより抑制される症状・検査所見と，抑制されな い所見，あるいは抗核抗体のプロファイルを明らか にすることでSLEにおける免疫異常がより明確に なると考えられる。

\section{抗 DNA 抗体の病原性}

比較的高頻度に認められ，かつ病原性を有する抗 核抗体のひとつに抗 DNA 抗体がある. 高力価の抗 DNA 抗体はSLE, 特にループス腎炎に特異性が高 くその抗体価は活動性と平行することが知られてい る。また SLE 患者の糸球体など傷害臓器から抗 DNA 抗体を溶出することが可能であり，正常マウ スに抗 DNA 抗体を投与することによってループス 腎炎の誘導が可能であると考えられている23). しか しながら，昨年 TLR (Toll-like receptor)-9 欠損マ ウスを用いた興味深いデータが報告された ${ }^{24,25)}$ （表 2). TLR は自然免疫に必須の分子で, 特に TLR-9 は B 細胞上に発現して $\mathrm{CpG}-\mathrm{DNA}$ モチーフを認識 し核酸に対するトレランスの破綻に関与する。 $\mathrm{CpG}-\mathrm{DNA}$ オリゴヌクレオチドを $\mathrm{MRL} / \mathrm{lpr}$ マウス に投与すると, 抗 DNA 抗体の産生がより刺激さ れ，ループス腎炎が増悪する26)。一方で TLR-9を 遺伝的に欠損した MRL/lpr マウスでは抗 U1RNP/ $\mathrm{Sm}$ 抗体は産生されるが, 抗 DNA 抗体の産生は認 められず，にもかかわらず免疫複合体性腎炎である ループス腎炎は野生型 MRL/lpr マウスと同様に発 症した ${ }^{24)}$.この結果は TLR-9 が抗 DNA 抗体の産 生に必要であることと同時に, 抗 DNA 抗体がルー プス腎炎発症の必要条件ではないことを示唆してい
る. もちろんこの成績は必ずしも抗 DNA 抗体の病 原性を否定するものではなく, 抗 U1RNP/Sm 抗体 であってもその免疫複合体が腎障害を引き起こす可 能性を示しているということができるであろう。一 方で, B 細胞表面のみに Ig が発現し, 分泌型 Ig を 欠損させた MRL/lpr マウス (mIgM MRL/lpr マウ ス）では，血清中の $\operatorname{IgG}$ は著しく低下し，抗核抗 体およびループス腎炎（免疫複合体性腎炎）は抑制 された ${ }^{27)}$ 。しかし間質性腎炎や腎血管炎は認めら れ，これらにおいては $\mathrm{T}$ 細胞がより重要な役割を 果たしている可能性が示唆された。 また CD40L を 遺伝的に欠損した MRL/lpr マウスでは抗 U1RNP/ $\mathrm{Sm}$ 抗体の産生は認められるが, 抗 DNA 抗体の産 生は全く認められずループス腎炎は抑制される99. TLR-9 欠損マウスと同様の抗体プロファイルであ るが，表現型として認められる病態が異なることは 興味深い。これらの成績は, 抗 DNA 抗体と抗 $\mathrm{U} 1 \mathrm{RNP} / \mathrm{Sm}$ 抗体の産生機序が明らかに異なり, 免 疫複合体性腎炎の発症に CD40L 発現自己反応性 T 細胞が必要であることを示している，前述したよう に，PCC-トランスジェニック MRL/lpr マウス (AND TCR transgenic TCR $\alpha-/-$ TCR $\beta-/-$ MRL/lpr マウス）では抗 DNA 抗体は陽性となる もののループス腎炎は発症しなかった ${ }^{8)}$ 。また C3H-lpr マウスでも抗 DNA 抗体の産生は認められ るが, ループス腎炎の発症はない28)。これらは, 抗 体価やアフィニティーの問題はあるが, 抗 DNA 抗 体単独の病原性に関して疑問を投げかける成績であ る. ヒト SLE では一部のサブクラスがより特異的 な病態と関連するという報告がある29)。これらは抗 体機能の差異のみでなく, それらのサブクラスを誘 導する自己反応性 Th1/Th2 細胞の差異により病態 が規定されている可能性を示すデータともいえるで あろう。

表 $2 \mathrm{MRL} / \mathrm{lpr}$ マウスにおける抗核抗体とループス腎炎の関係

\begin{tabular}{|c|c|c|c|c|}
\hline マウス* & 抗 U1RNP/Sm 抗体 & 抗 DNA 抗体 & (免疫複合体性腎炎) & 報告/年 \\
\hline $\mathrm{mIgM}$ & - & - & $\pm^{* *}$ & Chan OTM, et al/1999 \\
\hline CD40L $-/-$ & + & - & - & Ma J, et al/1996 \\
\hline TLR9 - / - *** & + & - & + & Christensen SR, et al $/ 2005$ \\
\hline $\begin{array}{l}\text { AND TCR transgenic } \\
\text { TCR } \alpha-/- \text { TCR } \beta-/-\end{array}$ & \pm & + & - & Peng S, et al/1996 \\
\hline
\end{tabular}

\footnotetext{
* 詳細は本文参照

** 間質性腎炎や血管炎の発症は認めたが, 糸球体病変は乏しかった.

*** TLR9 は, MRL/lpr マウスにおける抗DNA 抗体やループス腎炎に対し, 抑制的に働くという報告25)もある.
} 


\section{抗 DNA 抗体を標的とした治療の報告}

抗 DNA 抗体は病因的な抗核抗体であると考え, 抗 DNA 抗体の産生の抑制を目的とした治療法が古 くから提案されてきた (表 3) 30 38). 抗 DNA 抗体 それ自身を標的としたものもあるが，その産生に関 わる $\mathrm{T}$ 細胞や $\mathrm{B}$ 細胞を制御するものも多い。この ように抗 DNA 抗体の産生に関与する細胞を特異的 に制御し，その産生機序に関わるプロセスを包括的 に抑制することが最も有効性の高い治療と考えられ る. 使用する製剂とし, 特異的な配列を有したペプ チドの報告も多く, 実用化が期待される ${ }^{39)}$ ． EAE （実験的自己免疫性脳脊䯣膜炎）で示された $\mathrm{T}$ 細胞 ワクチネーションからヒト多発性硬化症におけるぺ プチド療法へと応用されているように, 近い将来ヒ トSLEにおいても新たな治療 strategy が生まれる ことを期待したい.

\section{抗 U1RNP/Sm 抗体が関連する病態とその関与}

抗 U1RNP 抗体は, SLEや混合性結合組織病 （MCTD）をはじめ, 強皮症, 多発性筋炎・皮膚筋 炎, 関節リウマチ, シェーグレン症候群など数多く の疾患で検出される抗核抗体である。レイノー現象 や白血球減少, 無菌性髄膜炎, 肺高血圧症などの臨 床症状との関連が古くから示唆されてはいるが, 血
清中抗 U1RNP 抗体そのものの病因的意義は乏しい と考えられている. 一方, 抗 Sm 抗体は, 抗 DNA 抗体と同様 SLE の疾患標識抗核抗体であり, SLE にきわめて特異性が高く, 遅発性腎症との関連40)や 中枢神経症状との関連 ${ }^{41)}$ が指摘されてきた。われわ れは MCTD やSLE 患者において無菌性髄膜炎を はじめとした中枢神経症状 (neuropsychiatric lupus) を呈する患者では血清中に抗 U1RNP 抗体が高頻度 に見いだされること ${ }^{42}$ に注目し，脳脊髄液（CSF） 中の抗 U1RNP 抗体を測定した。興味深いことに, 原病に関連した中枢神経症状の場合にのみ, CSF 中の抗 U1RNP 抗体が陽性となり, 血清中に比し濃 縮されていた．血清中の抗 U1RNP 抗体が強陽性で あっても, 薬剤性髄膜炎や, ステロイドや免疫抑制 薬を増量することなく抗精神病薬のみでコントロー ルできた症例では陰性であった。 さらに抗 U1RNP 抗体をU1RNP を構成する蛋白成分に対する抗体に 分けて検討したところ, CSFにおいては, 抗 A/C 抗体に比し抗 $70 \mathrm{~K}$ 抗体の濃縮が著明であった. 図 2 に, MCTD の再燃と同時に無菌性髄膜炎を発症 し, IgG で補正した髄液中の抗 U1RNP 抗体が血清 中に比し高值であり, その值が $I g G$ index よりもよ く中枢神経症状の活動性と平行した症例を示す。こ れらの臨床所見は, CSF 中の抗 U1RNP 抗体が neuropsychiatric lupus の診断あるいは活動性のよ

表 3 抗 DNA 抗体を標的としたループスモデルマウスの治療実験

\begin{tabular}{|c|c|c|c|}
\hline モデルマウス & 使用したペプチド・細胞 & 効 & 報告者/年 \\
\hline NZB/NZW F1 & $\begin{array}{l}3 \text { 種類の } \mathrm{V}_{\mathrm{H}} \text { ペプチド混合（A6.1 } \\
\left.\mathrm{V}_{\mathrm{H}} \mathrm{p} 34, \mathrm{p} 58, \mathrm{p} 84\right)\end{array}$ & $\begin{array}{l}\text { 発症前投与で抗 DNA 抗体と腎症の } \\
\text { 抑制, 生存率の向上 } \\
\text { 発症後投与は効果なし }\end{array}$ & Singh, et al/1995 \\
\hline $\begin{array}{l}\text { 抗 DNA 抗体 } \\
(16 / 6 \mathrm{Id}) \text { 誘導ルー } \\
\text { プス }\end{array}$ & pCDR1, pCDR3 & 抗 DNA 抗体の抑制 & Waisman, et al/1997 \\
\hline SCID マウス & 抗 DNA 抗体に結合するペプチド & Ig の腎沈着抑制 & Gaynor, et al/1997 \\
\hline SWR/NZR F1 & $\mathrm{H} 2 \mathrm{~B}_{10-33}, \mathrm{H} 4_{16-39}, \mathrm{H} 4_{71-94}$ & $\begin{array}{l}\text { 発症前投与で腎症の抑制 } \\
\text { 発症後投与で生存率向上と腎症の悪 } \\
\text { 化抑制 }\end{array}$ & Kaliyaperumal, et al/1999 \\
\hline NZB/NZW F1 & 自然自己抗体の $V_{H}$ CDR3 & 蛋白尿の抑制と生存率向上 & Jouanne, et al/1999 \\
\hline NZB/NZW F1 & $\begin{array}{l}\text { 抗 DNA 抗体投与により誘導される } \\
\text { pCDR3 }\end{array}$ & 疾患の抑制 & Eilat, et al/2000 \\
\hline NZB/NZW F1 & Consensus VH & $\begin{array}{l}\text { 抗 DNA 抗体と腎症の抑制 } \\
\text { 生存率向上 }\end{array}$ & Hahn, et al/2000 \\
\hline $\mathrm{MRL} / l p r$ & Ig に結合するぺプチド（TG19320） & $\begin{array}{l}\text { 抗 DNA 抗体と腎症の抑制 } \\
\text { 生存率向上 }\end{array}$ & Marino, et al/2000 \\
\hline NZB/NZW F1 & $\begin{array}{l}\text { ヌクレオゾーム特異的 TCR/ } \\
\text { CTLA4Ig 発現 } \mathrm{T} \text { 細胞 }\end{array}$ & $\begin{array}{l}\text { 抗ヌクレオゾーム/dsDNA/ヒストン } \\
\text { 抗体と腎症の抑制 }\end{array}$ & Fujio, et al/2004 \\
\hline
\end{tabular}




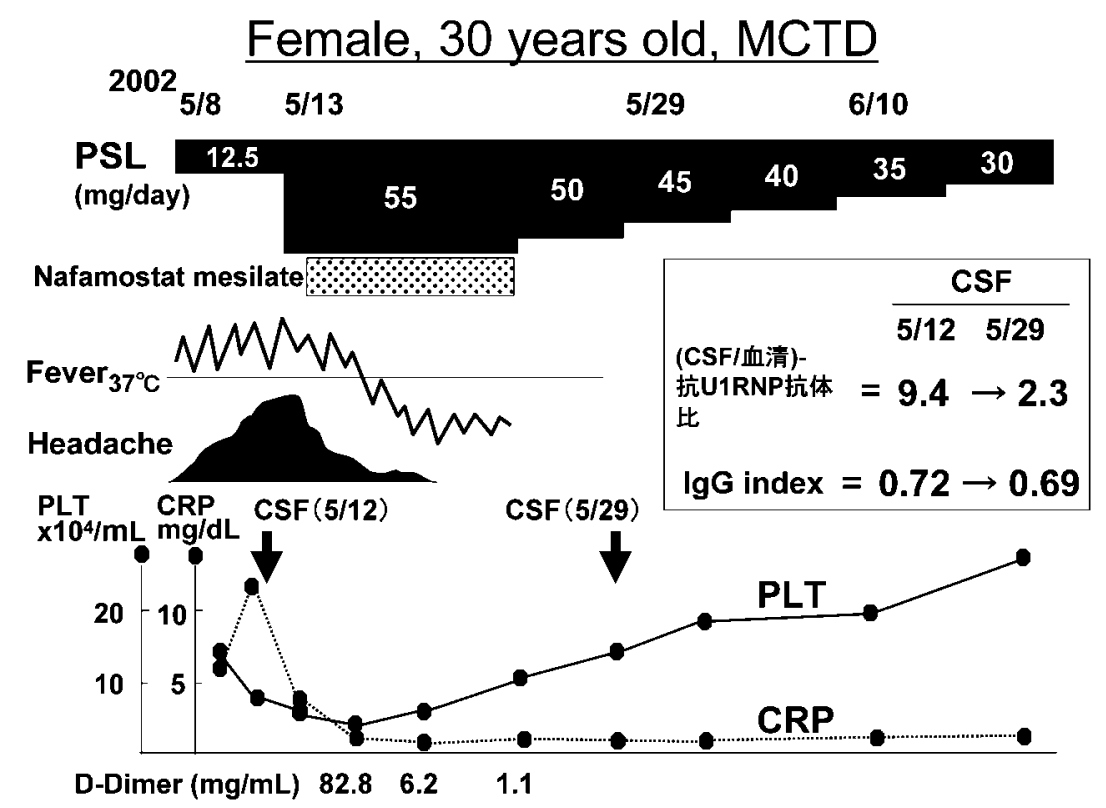

図 2 脳脊髄液中に抗 U1RNP 抗体が検出され, IgG で補正した抗 U1RNP 抗体比（脳脊髄液と血清の比）が無菌性髄膜炎の活動 性指標となった 1 例

2002 年 5 月から頭痛と発熱が出現, 当院受診時項部硬直をみとめた。 D-Dimer 高值をともなう血小板数の低下があり，MCTD の活動性に伴う無菌性髄膜炎とDIC の合併と考え, ステロイドを増量した。脳脊䯣液（CSF）中の蛋白および細胞数も上昇して いたが，培養は陰性であった。非ステロイド抗炎症薬による無菌性髄膜炎も疑ったが被疑薬剤のリンパ球刺激試験はすべて陰性 であった. プレドニゾロン（PSL）増量後，発熱と頭痛は速やかに消失し，血小板数も増加した．経過中 2 回 CSF の採取を行っ たが，急性期に (CSF/血清)-抗 U1RNP 抗体比が高く, CSF 中で抗 U1RNP 抗体が濃縮されている可能性が考えられた。 また治 療後, 同比は低下したが，本例では IgG index よりもよりよい指標であった.

い指標であること，かつ限られた病変局所において 抗 U1RNP 抗体が病因的意義を持ちうる可能性を示 唆している.

最近，アメリカ陸軍の保存血清をもちいて経時的 に抗核抗体を検出した成績が報告された ${ }^{43)}$. 興味深 いことに抗 U1RNP 抗体と抗 Sm 抗体は，他の抗核 抗体あるいは自己抗体（抗 DNA 抗体，抗 SSA/Ro 抗体, 抗 SSB/La 抗体, 抗リン脂質抗体）に比べ, より臨床症状出現の直近（半年以内）で抗体が陽転 化していた。この現象は抗核抗体の病原性を直接的 に示すものではないが，他の抗核抗体が 1 ～年以 上前から出現していることを考えると，抗 U1RNP 抗体や抗 $\mathrm{Sm}$ 抗体は疾患の発症を予測するマーカー としては重要であると考えられる.

\section{おわりに}

TNF 阻害療法をはじめとし，関節リウマチの治 療は著しく進歩した。一方で SLE など膠原病の治 療は未だ非特異的な免疫抑制療法であり，感染症な どの副反応が大きな問題になっている．SLE 治療 としてリツキシマブの有効性が示唆されているよう に， $\mathrm{B}$ 細胞や活性化 $\mathrm{T}$ 細胞を標的としたより特異 的な細胞レベルでの治療が今後考慮されるべきであ
ろう。そのためにも，いかなる抗核抗体を標的ある いはマーカーとするかが大切であり，抗核抗体のよ り詳細な産生機序や病原性を明らかにすることは膠 原病診療において解決しなければいけない問題であ ると考えられる。

\section{文献}

1) Hargraves MM, Richmond BS, Morton R : Presentation of two bone marrow elements: The "tart" cell and the "L.E." cell. Proc Mayo Clin 23 : 25-28, 1948.

2) Tan EM : Antinuclear antibodies : Diagnostic markers for autoimmune diseases and probes for cell biology. Adv Immunol 44:93-151, 1989.

3）三森経世：抗核抗体研究の進歩一自己抗体が 認識する核および細胞質蛋白の構造と機能 一. リウマチ 32: 366-378, 1992.

4) Sclomchik, MJ, Craft J, Mamula MJ : From $T$ to $\mathrm{B}$ and back again : Positive feedback in systemic autoimmune disease. Nat Rev Immunol $1:$ 147-153, 2001.

5) Craft J, Peng S, Fujii T, et al. : Autoreactive $T$ cells in murine lupus. Immunological Res 19 : 245-257, 1999. 
6) Peng SL, Madaio MP, Hayday AC, et al. : Propagation and regulation of systemic autoimmunity by $\gamma \delta \mathrm{T}$ cells. J Immunol $157: 5689-$ 5698, 1996.

7) Peng SL, Madaio MP, Hughes DPM, et al. : Murine lupus in the absence of $\alpha \beta$ T cells. J Immunol 156 : 4041-4049, 1996.

8) Peng SL, Fatenejad S, Craft J : Induction of nonpathogenic, humoral autoimmunity in lupus-prone mice by a class II-restricted, transgenic $\alpha \beta \mathrm{T}$ cell. Separation of autoantigenspecific and -nonspecific help. J Immunol 157 : 5225-5230, 1996.

9) Ma J, Xu J, Madaio MP, et al. : Autoimmune lpr/lpr mice deficient in CD40 ligand. Spontaneous Ig class switching with dichotomy of autoantibody responses. J Immunol 157 : 417426, 1996.

10) Early GS, Zhao W, Burns CM : Anti-CD40 ligand antibody treatment prevents the development of lupus-like nephritis in a subset of New Zealand Black $x$ New Zealand White mice. Response correlates with the absence of an antiantibody response. J Immunol 157 : 3159-3164, 1996.

11) Yan J, Mamula MJ : B and T cell tolerance and autoimmunity in autoantibody transgenic mice. Int Immunol 14 : 963-971, 2002.

12) Crispin JC, Martinez A, Alcocer-Varela, J : Quantification of regulatory $\mathrm{T}$ cells in patients with systemic lupus erythematosus. J Autoimmun 21 : 273-276, 2003.

13) Lin R-H, Mamula MJ, Hardin JA, et al. : Induction of autoreactive $\mathrm{B}$ cells allows priming of autoreactive T cells. J Exp Med 173 : 14331439, 1991.

14) Vratsanos GS, Jung S, Park Y-M, et al. : CD4 ${ }^{+}$ $\mathrm{T}$ cells from lupus-prone mice are hypertensive to $\mathrm{T}$ cell receptor engagement with low and high affinity peptide antigens : A model to explain spontaneous $\mathrm{T}$ cell activation in lupus. $J$ Exp Med 193 : 329-337, 2001.

15) Monk CR, Spachidou M, Rovis F, et al. : MRL /Mp CD4+, CD25- $\mathrm{T}$ cells show reduced sensitivity to suppression by $\mathrm{CD} 4+, \mathrm{CD} 25+$ regulatory $\mathrm{T}$ cells in vitro. A novel defect of $\mathrm{T}$ cell regulation in systemic lupus erythematosus. Arthritis Rheum 52 : 1180-1184, 2005

16) Higuchi $T$, Aiba $Y$, Nomura $T$, et al. : Cutting edge : Ectopic expression of CD40 ligand on B cells induces lupus-like autoimmune disease. $J$
Immunol 168 : 9-12, 2002.

17) Dasai-Mehta A, Lu L, Ramsey-Goldman, R, et al. : Hyperexpression of CD40 ligand by B and $\mathrm{T}$ cells in human lupus and its role in pathogenic autoantibody production. J Clin Invest 97 : 2063-2073, 1996.

18) Koshy M, Crow MK : Increased expression of CD40 ligand on systemic lupus erythematosus lymphocytes. J Clin Invest 98 : 826-837, 1996.

19) Grimaldi CM, Hicks R, Diamond B : B cell selection and susceptibility to autoimmunity. $J$ Immunol 174 : 1775-1781, 2005.

20) Sfikakis PP, Boletis JN, Lionaki S, et al. : Remission of proliferative lupus nephritis following B cell depletion therapy is proceeded by down-regulation of $\mathrm{T}$ cell costimulatory molecule CD40 ligand. An open-labeled trail. Arthritis Rheum 52 : 501-513, 2005.

21) Anolik JH, Barnard J, Cappione A, et al. : Rituximab improves peripheral B cell abnormalities in human systemic lupus erythematosus. Arthritis Rheum 50 : 3580-3590, 2004.

22) Yurasov S, Wardemann H, Hammersen J, et al. : Defective B cell tolerance checkpoints in systemic lupus erythemtosus. J Exp Med 201 : 703-711, 2005.

23) Harn BH : Antibodies to DNA. $N$ Engl J Med 338 : 1359-1368, 1998.

24) Christensen SR, Kashgarian M, Alexopoulou L, et al. : Toll-like receptor 9 controls antiDNA autoantibody production in murine lupus. J Exp Med 202 : 321-331, 2005.

25) Wu X, Peng SL : Toll-like receptor 9 signaling protects against murine lupus. Arthritis Rheum 54 : 336-342, 2006.

26) Anders H-J, Vielhauer V, Eis V, et al. : Activation of toll-like receptor-9 induces progression of renal disease in MRL-Fas (lpr) mice. FASEB J 18 : 534-536, 2004.

27) Chan OTM, Hannum LG, Haberman AM, et al. : A novel mouse with $\mathrm{B}$ cells but lacking serum antibody reveals an antibody-independent role for B cells in murine lupus. J Exp Med 189 : 1639-1647, 1999.

28) Izui S, Kelly VE, Masuda K, et al. : Induction of various autoantibodies by mutant gene lpr in several strains of mice. J Immunol 133 : 227233, 1984.

29) Bijl N, Dijstelbloem HM, Oost WW, et al. : IgG subclass distribution of autoantibodies differs between renal and extra-renal relapses in 
patients with systemic lupus erythematosus. Rheumatology 41 : 62-67, 2002.

30) Singh RR, Ebling FM, Sercarz EE, et al. : Immune tolerance to autoantibody-derived peptides delays development of autoimmunity in murine lupus. J Clin Invest 96 : 2990-2996, 1995.

31) Waisman A, Ruiz PJ, Israeli E, et al. : Modulation of murine systemic lupus erythematosus with peptides based on complimentarity determining regions of a pathogenic anti-DNA monoclonal antibody. Proc Natl Acad Sci USA 94 : 4620-4625, 1997.

32) Gaynor B, Putterman C, Valadon P, et al. : peptide inhibition of glomerular deposition of an anti-DNA antibody. Proc Natl Acad Sci USA 94 : 1955-1960, 1997.

33) Kaliyaperumal A, Michaeles MA, Datta SK : Antigen-specific therapy of murine lupus nephritis using nucleosomal peptides: Tolerance spreading impairs pathogenic function of autoimmune $\mathrm{T}$ and $\mathrm{B}$ cells. J Immunol 162 : 5775-5783, 1999.

34) Jouanne C, Avrameas S, Payelle-Brogard B : A peptide derived from a polyreactive monoclonal anti-DNA natural antibody can modulate lupus development in (NZB x NZW) F1 mice. Imunology 96 : 333-339, 1999.

35) Eilat E, Dayan $M$, Zinger $H$, et al. : The mechanism by which a peptide based on complementarity-determining region-1 of a pathogenic anti-DNA auto-Ab ameliorates experimental systemic lupus erythematosus. Proc Natl Acad Sci USA 98 : 1148-1153, 2001.

36) Harn BH, Singh RR, Wong WK, et al. : Treat- ment with a consensus peptide based on amino acid sequences in autoantibodies prevents $\mathrm{T}$ cell activation by autoantigens and delays disease onset in murine lupus. Arthritis Rheum 44 : 432-441, 2001.

37) Marino M, Ruvo M, De Falco S, et al. : Prevention of systemic lupus erythematosus in MRL/ lpr mice by administration of an immunoglobulin-binding peptide. Nat Biotechnol 18 : 735-739, 2000.

38) Fujio K, Okamoto A, Tahara H, et al. : Nuceleosome-specific regulatory $\mathrm{T}$ cells engineered by triple gene transfer suppress a systemic autoimmune disease. J Immunol 173 : 2118-2125, 2004.

39) Singh RR : The potential use of peptides and vaccination to treat systemic lupus erythematosus. Curr Opin Rheumatol 12 : 399-406, 2000.

40) Homma M, Mimori T, Takeda Y, et al. : Autoantibodies to the Sm antigen : Immunological approach to clinical aspects of systemic lupus erythematosus. J Rheumatol $14: 188-193$, 1987.

41) Yasuma M, Takasaki Y, Matsumoto K, et al. : Clinical significance of IgG anti-Sm antibodies in patients with systemic lupus erythematosus. $J$ Rheumatol 17 : 469-475, 1990.

42) Okada J, Hamana T, Kondo H : Anti-U1RNP antibody and aseptic meningitis in connective tissue diseases. Scand J Rheumatol 32 : 247252, 2003.

43) Arbuckle MR, McClain MT, Rubertone MV, et al. : Development of autoantibodies before the clinical onset of systemic lupus erythematosus. N Engl J Med 349 : 1526-1533, 2003. 